\title{
MENIMBANG ULANG APOKALIPS KITAB DANIEL
}

\author{
YONKY KARMAN*
}

\begin{abstract}
Abstrak: Pembacaan atas aspek apokaliptik Kitab Daniel sering dipusatkan pada bagian kedua kitab itu (Dan. 7-12). Bagian pertamanya (Dan. 1-6) hanya dibaca sebagai cerita-cerita heroisme iman. Dengan begitu, sifat apokaliptik tidak kelihatan sebagai karakteristik kitab itu secara keseluruhan. Apokalips sendiri cenderung dikaitkan dengan eskatologi, dan bagian kedua kitab tersebut secara mencolok memakai kata "akhir." Pengaitan aspek apokaliptik dengan fatalisme akhir zaman berkembang di kalangan sekte kiamat. Kendati aspek eskatologisnya, apokalips seharusnya juga dipahami dalam matriks hikmat. Jika dibaca dalam kesatuan dan keutuhannya, kitab itu memperlihatkan gagasan mengenai hidup berhikmat dalam mengantisipasi kiamat, bukan dengan menarik diri dari dunia, melainkan setia kepada Allah dan kritis terhadap arogansi kekuasaan.
\end{abstract}

Kata-kata Kunci: Apokalips, apokaliptik, kiamat, radikal, Makabe, sektarian, nubuat, hikmat, eskatologi.

Abstract: The reading of the apocalyptic aspect of the Book of Daniel often focuses on the book's second part (Dan. 7-12). The first part (Dan. 1-6) is usually read as an account of stories of faithful heroism. In this manner, the apocalyptic dimension is not seen as characteristic of the book as a whole. Apocalypse itself tends to be associated with eschatology, and indeed the second part of the book strikingly makes use of the word "end." The association of apocalypse with the fatalism of the end time has developed within the doomsday sect. Despite its eschatological dimension, the apocalyptic aspect should be read within the matrix of wisdom. When read in its unity and integrity, the book demonstrates the idea of living wisely in anticipation of the end, not by

* Yonky Karman, Sekolah Tinggi Teologi Jakarta, Jl. Proklamasi 27, Jakarta 10320, Email:karmanyonky@gmail.com 
withdrawing oneself from the world, but by being faithful to God and by being critical of the arrogance of power.

Keywords: Apocalyptic, doomsday, radical, Maccabees, sectarian, prophecy, wisdom, eschatology.

\section{PENDAHULUAN}

Tema apokalips kerap dikaitkan dengan kiamat, sebuah tema yang akrab bagi masyarakat Indonesia, seperti dalam judul film Kiamat Sudah Dekat (2003), yang kemudian dibuat versi sinetronnya. Tema apokalips tidak hanya populer di lingkungan religius, tetapi sudah menjadi bagian dari kesadaran modern sebagaimana terlihat dari karya-karya fiksi ilmiah, novel, atau film yang menggambarkan masa depan suram dunia karena peningkatan kerusakan lingkungan, krisis pangan, pertumbuhan penduduk miskin, kesenjangan sosial, dan seterusnya. Pada dirinya, sastra apokalips tergolong sastra krisis. ${ }^{1}$

Sastra apokalips berciri esoteris (rahasia, untuk kalangan sendiri) dan karena itu sering dibaca sebagai peta masa depan yang menempatkan pembacanya seperti sedang hidup di waktu-waktu zaman akhir. Dalam konteks Alkitab, apokalips adalah bentuk tulisan yang berfokus pada perkara-perkara akhir zaman, kapan dunia ini berakhir dan kejahatan disingkirkan untuk selamanya melalui intervensi Allah, kapan dunia baru mulai dan semua orang mati dibangkitkan untuk pengadilan akhir. Era keselamatan eskatologis mulai dengan berlakunya ganjaran abadi, bagi orang jahat maupun orang baik. Dunia ini berikut tatanannya akan berakhir dan membuka jalan bagi dunia lain dari atas yang identik dengan pemerintahan universal Allah. Pada dirinya, sastra apokalips dalam Alkitab tidak hanya berbicara tentang krisis tetapi juga pengharapan. ${ }^{2}$

Dalam rangka mengantisipasi dunia baru, komunitas apokaliptik biasanya acuh tak acuh terhadap dunia lama. Sekte-sekte kiamat (doomsday

1 Mitchell G. Reddish, ed., Apocalyptic Literature: A Reader (Nashville: Abingdon Press, 1990), p. 24.

2 D.S. Russell, The Method and Message of Jewish Apocalyptic: 200 BC-AD 100 (Philadelphia: Westminster Press, 1964), p. 18. 
religions) menganggap dunia digerakkan oleh nilai-nilai yang membawa dunia kepada kehancuran total. Orang di luar komunitas mereka dianggap bebal. Komunitas sektarian pun secara eksklusif mempraktikkan nilai-nilai yang diyakini akan berlaku untuk dunia baru. Mereka ketat dengan kemurnian ajaran dan disiplin anggota. Demikian kurang lebih pandangan hidup sekte Eseni (Yahudi) yang menjauhkan diri dari keramaian Yerusalem dan menyepi ke gua-gua di Qumran, Laut Mati (250 SM-70 M). Dalam agama Kristen ada Gereja Pondok Nabi (2003) di Bandung, yang dipimpin Mangapin Sibuea. Sektarianisme apokaliptik dapat mengambil bentuk radikal lain. Sekte Hari Ketujuh bernama Tunas Daud (1993) pimpinan David Koresh bertahan di Mount Carmel, Waco (Texas), dari pengepungan Biro Alkohol, Tembakau, dan Senjata Api (BATF) dan Biro Investigasi Federal (FBI) selama hampir dua bulan. Akhirnya, markas itu diluluhlantakkan dan seluruh delapan puluh dua anggota komunitas itu tewas, termasuk anak-anak. ${ }^{3}$

Karena lekat dengan label sektarian, kanonisitas tulisan apokaliptik sering diragukan. Banyak bacaan apokaliptik Yahudi hanya menjadi konsumsi di lingkungan pribadi, sekte, ataupun agama misteri. ${ }^{4}$ Tema apokaliptik pun cenderung dianaktirikan dalam diskursus teologi. Dalam Perjanjian Lama, hanya Kitab Daniel yang secara utuh dianggap sebagai sebuah kitab apokaliptik. Kitab itu sering dikaitkan dengan pemberontakan Makabe melawan penguasa lalim. Dari situ genre apokaliptik didefinisikan, muncul dan berkembang di lingkungan Yahudi dan Kristen selama periode 200 SM-100 M, salah satu periode dalam sejarah Yahudi dan Kristen yang paling heroik sekaligus tragis. ${ }^{5}$

3 Sepasang mata burung hantu pada logo Densus 88 mungkin dikaitkan dengan eksekusi berciri apokaliptik atas sebuah pemberontakan di Cirebon pada 1818. Lih. Tandi Skober, “Apokaliptisisme Densus 88," Media Indonesia, 8 September 2012, Opini: 25.

4 Max Weber, Ancient Judaism, translated by H.H. Gerth and D. Martindale (New York: Free Press, 1952), p. 380.

5 D.S. Russell, The Method and Message of Jewish Apocalyptic, pp. 15-20; Henk ten Napel, Kamus Teologi Inggris-Indonesia (Jakarta: BPK Gunung Mulia, 1994), hlm. 35-36; Gerald O'Collins and Edward G. Farrugia, Kamus Teologi, terjemahan: I. Suharyo (Yogyakarta: Kanisius, 1996), hlm. 31. 


\section{MATRIKS APOKALIPTIK}

Berbeda dari cara membaca Kitab Daniel yang menjadikan Revolusi Makabe ataupun nubuat sebagai matriks (kerangka acuan) apokaliptik kitab itu, artikel ini mengindikasikan unsur-unsur pra-Makabe dan matriks hikmat untuk apokalips kitab itu. ${ }^{6}$

\section{Nubuat}

Membaca Kitab Daniel dalam matriks nubuat tidak dapat dipisahkan dari posisi kitab itu dalam kanon Yunani (Septuaginta), kemudian juga kanon Latin (Vulgata). Dalam kedua kanon itu, letak Kitab Daniel di antara Kitab Nabi-nabi Besar (Yesaya, Yeremia, dan Yehezkiel) dan Kitab Nabinabi Kecil (Hosea sampai Maleakhi) membuat kitab itu dibaca sebagai sebuah kitab nabi. Memang kitab itu memuat nubuat untuk peristiwaperistiwa yang akan datang, penglihatan, ihwal perang antarbangsa dan pemerintahan Allah sebagai raja. ${ }^{7}$ Padahal, kitab itu dalam kanon Yahudi tidak termasuk korpus nĕbi'im (Kitab Nabi-nabi). Ada indikasinĕbi'im sudah tertutup menjelang akhir abad ke-3 SM dan Kitab Daniel berasal dari masa sesudah itu. ${ }^{8}$

Latar waktu Kitab Daniel adalah periode Imperium Babel (abad ke-6 SM) dan tahun-tahun awal Imperium Persia, namun penyataan yang diterima Daniel terkait peristiwa-peristiwa yang terjadi di Yerusalem merujuk periode Helenistik (abad ke-2 SM). Kitab itu dengan tepat memprediksi serangkaian peristiwa yang terjadi hanya sampai masa penindasan dan penganiayaan dari Antiokhus IV Epifanes (175-164 SM), namun tidak akurat untuk beberapa data historis yang cukup jauh dari waktu itu. Antiokhus sendiri menganggap diri lebih besar dari ilah apa pun (bdk. Dan. 11:36), bahkan lebih besar dari ilah yang disembah nenek moyangnya,

6 John J. Collins, The Apocalyptic Imagination: An Introduction to Jewish Apocalyptic Literature, Second edition, The Biblical Resource Series (Grand Rapids: Eerdmans, 1998), pp. 87-90.

7 W.S. LaSor, D.A. Hubbard, dan F.W. Bush, Pengantar Perjanjian Lama 2: Sastra dan Nubuat, terjemahan: L.W. Tjiputra (Jakarta: BPK Gunung Mulia, 1994), hlm. 408-411.

8 Louis F. Hartman and Alexander A. Di Lella, The Book of Daniel, The Anchor Bible 23 (New York: Doubleday, 1978), p. 25; Rolf Rendtoff, The Canonical Hebrew Bible: A Theology of the Old Testament, translated by David E. Orton (Leiden: Deo, 2005), p. 387. 
termasuk Tamus (bdk. Yeh. 8:14), dewa kesuburan, yang tidak hanya popu-ler di kalangan perempuan (bdk. *Dan 11:37 "pujaan para wanita"). ${ }^{9}$ Seba-gai gantinya, Antiokhus menyembah Zeus, dewa Yunani (bdk. Dan. 11:38: "dewa benteng-benteng, dewa yang tidak dikenal oleh nenek moyangnya"). Zeus mengandalkan senjata perang untuk menyebarluaskan agamanya.

Antiokhus pun melecehkan agama Yahudi. Kesombongannya mencapai puncaknya dalam pembuatan patung Zeus dengan wajah yang mirip dirinya, dan ia menyebut dirinya sendiri Epifanes, manifestasi yang ilahi. Pada Desember 168 SM, pasukan Antiokhus menyerang Bait Suci dan menajiskannya dengan babi (haram bagi orang Yahudi) sebagai hewan kurban di atas mezbah dan memaksa orang Yahudi memakan dagingnya. Ia juga memberi kurban kepada dewa-dewa, melarang pelaksanaan hari Sabat dan hari-hari raya keagamaan Yahudi lainnya (bdk. Dan. 8:14: "suatu kebaktian diadakan secara fasik menggantikan kurban sehari-hari"; 11:31: "menajiskan tempat kudus ... menghapuskan kurban sehari-hari dan menegakkan kekejian yang membinasakan"). Bahkan, ia menghentikan ritual sunat bagi orang Yahudi yang merupakan sebuah tanda keumatan. Ia meletakkan patung itu di atas mezbah orang Yahudi agar disembah sebagai pengganti Allah Israel.

Menolak titah Antiokhus berarti menerima penganiayaan atau hukuman mati. Sebagian orang Yahudi ditangkap, namun mereka tidak gentar (bdk. Dan 11:32: “tetapi umat yang mengenal Allahnya akan tetap kuat dan akan bertindak"). Banyak orang Yahudi saat itu menderita karena iman mereka (1Mak. 1:41-63). Mereka siap menjadi martir. Tawaran bantuan militer dari pihak lain (bdk. Dan. 11:34: "pertolongan sedikit") tidak mereka gubris sebab penderitaan itu mereka anggap sebagai ujian iman (bdk. Dan. 11:35: "penyaringan dan pemurnian di antara mereka;" 12:10: "disucikan dan dimurnikan dan diuji"). Demikian selama tiga tahun praktis ibadah di Bait Suci terhenti, sampai akhirnya Revolusi Makabe berhasil. Kitab Daniel pun diperkirakan ditulis sekitar 166 SM untuk

9 Tanda $\left(^{*}\right)$ merujuk Alkitab versi Bahasa Indonesia Sehari-hari (LAI). 
memompa semangat para pejuang dalam Revolusi Makabe melawan Antiokhus, dan penulisnya bukan Daniel. ${ }^{10}$ Penulis kitab itu bernubuat untuk peristiwa-peristiwa yang sudah terjadi (vaticinia ex eventu). ${ }^{11}$ Tujuan utama pemakaian nubuat-nubuat ex eventu adalah untuk menambah otoritas penulis kitab dan juga memberi jaminan kepada umat bahwa pengharapan mereka tidak sia-sia. ${ }^{12}$

Kendati demikian, tradisi Daniel dalam Septuaginta dan Naskahnaskah Laut Mati mengindikasikan bahwa Kitab Daniel dalam bentuk lengkap sudah tersebar di suatu wilayah yang relatif cukup luas sebelum masa Antiokhus. ${ }^{13}$ Tambahan-tambahan pada Kitab Daniel (Doa Azarya, Lagu Pujian Ketiga Pemuda, Kisah Susana dan Daniel, Daniel dengan Dewa Bel dan Naga Babel) secara konsisten hadir dalam teks Yunani Septuaginta dan Theodotion, namun tidak menjadi bagian dari Teks Masora (yang ber-bahasa Ibrani dan sedikit Aram). Doa Nabonidus dari Gua ke-4 Qumran bersifat paralel dengan kisah Nebukadnezar yang hilang ingatan (Dan. 4:22-37/19-34). ${ }^{14}$ Tradisi apokaliptik sudah ada sebelum Makabe. Dalam siklus Henokh (rangkaian cerita yang terpusat pada seorang tokoh), bagian-bagian paling awal Kitab Henokh (versi Etiopia, 1 Henokh) diketahui berasal dari masa pra-Makabe, yakni pada abad ke-3 SM. $\cdot{ }^{15}$ Dua buku pertama Kitab Henokh (Buku Para Pengawal dan Buku Benda-benda Langit), ditulis sebelum munculnya tiga kelompok keagamaan semasa Makabe (Farisi, Saduki, dan Eseni) dan hanya diterima di lingkungan sempit Yahudi, seperti juga kemudian dua buku terakhir kitab itu (Perumpamaan-perumpamaan Henokh dan Apokalips Hewan) dikaitkan dengan

10 J. Blommendaal, Pengantar kepada Perjanjian Lama (Jakarta: BPK Gunung Mulia, 1979), hlm. 166.

11 Penulis Kitab Mormon memakai teknik vaticinia ex eventu dalam menggambarkan Yeshua, Injil, dan periode dalam Perjanjian Baru.

12 Mitchell G. Reddish, ed., Apocalyptic Literature, p. 23.

13 W.S. LaSor, D.A. Hubbard, dan F.W. Bush, Pengantar Perjanjian Lama, hlm. 417.

14 Angka ayat sebelum tanda (/) merujuk teks Alkitab dan sesudahnya merujuk teks Ibrani Alkitab.

15 John J. Collins, The Apocalyptic Imagination, pp. 24-25, 59; Rainer Albertz, A History of Israelite Religion in the Old Testament Period, Vol. 2, translated by J. Bowden (Louisville: Westminster John Knox Press, 1994), p. 565. 
sekte Eseni. Meski sering dikaitkan dengan Buku Para Pengawal (dari awal abad ke-2SM atau mungkin akhir abad ke-3 SM), Kitab Daniel justru diterima di lingkungan luas Yahudi (sebagai bagian dari kanon Yahudi) sehingga sifat apokaliptiknya tidak berciri sektarian. ${ }^{16}$

Isi sastra apokalips lebih luas dari pada soal akhir zaman. Buku Para Pengawal, misalnya, memberi jaminan bagi umat yang mengalami guncangan budaya. Isi perumpamaan-perumpamaan Henokh menguatkan umat yang secara sosial merasa tidak berdaya. Buku Apokalips Hewan (semua tokohnya mengambil sosok hewan) menggambarkan berakhirnya sejarah umat manusia (dari Adam dan Hawa sampai Mesias). Buku Bendabenda Langit bertujuan agar umat tidak salah menghitung kalender matahari yang seharusnya 364 hari. Selanjutnya, Kitab 2 dan 3 Barukh dimaksudkan untuk reorientasi umat sesudah pengalaman sejarah yang traumatis. Kitab 4 Ezra menghibur umat yang merasa nasib mereka suram. Kitab Wasiat Abraham menghibur umat yang masygul dengan kematian sebagai takdir manusia. Kitab Wasiat Lewi 2-5 menggambarkan pengalaman ekstase mendapat penglihatan yang melegitimasi klaim dinasti Hasmone (140-37 SM) atas jabatan raja (wilayah Yudea) sekaligus posisi Imam Besar. Dalam Perjanjian Lama, nabi awalnya adalah orang yang mendapat suatu penglihatan dari Allah untuk disampaikan kepada orang lain dan karena itu disebut pelihat (1Sam. 9:9).

Menurut von Rad, apokalips bukan bentuk lain ataupun kelanjutan nubuat. ${ }^{17}$ Sang apokaliptis tidak meneruskan tradisi nubuat, tidak menjadi nabi bagi zamannya, tidak menghibur pembaca, tidak mengajak orang bertobat sebagaimana biasanya dilakukan nabi. Ia hanya mempelajari nubuat-nubuat masa lalu sebagai bagian dari tradisi nubuat yang, menurut von Rad, sudah berakhir dengan Kitab Maleakhi dan Zakharia Ketiga (Za. 12-14). Apokalips adalah produk sebuah gerakan intelektual di luar tradisi nubuat. Sang apokaliptis lebih merupakan orang bijak pemegang

16 Roger Beckwith, The Old Testament Canon of the New Testament Church (Grand Rapids: Eerdmans, 1985), pp. 357-358.

17 Gerhard von Rad, Old Testament Theology, Vol. 2, translated by W.G. Stalker (New York: Harper \& Row, 1965), pp. 297-306; Rainer Albertz, A History of Israelite Religion, p. 565. 
kunci rahasia akhir zaman. Selanjutnya, von Rad mengindi-kasikan hikmat sebagai rahim apokalips, sebuah asumsi teologis yang pernah muncul sebelumnya pada abad ke-19. ${ }^{18}$ Tema hikmat secara konsisten ada di seluruh Kitab Daniel.

\section{НiKMAT}

Dalam kanon Yahudi, Kitab Daniel termasuk korpus kĕtubim(Hagiographa) bersama Kitab Ayub, Amsal, dan Pengkhotbah (yang tergolong kitab-kitab hikmat). Sejak awal, figur Daniel tampil sebagai orang yang dikaruniai Allah berbagai-bagai hikmat (Dan. 1:4,17), dengan hikmat yang mengungguli hikmat orang Babel (Dan. 2, 4,5). Allah dipuji sebagai sumber hikmat (Dan. 2:21). Orang bijak "membuat banyak orang mengerti" hukum-hukum Tuhan dan rahasia-rahasia yang diterima dari penglihatan mimpi (Dan. 11:33), "menuntun banyak orang kepada kebenaran" (Dan. 12:3). Yang menarik, para martir dalam penganiayaan Antiokhus juga disebut orang bijak (Dan. 11:33,35; 12:3,10). Tokoh Daniel ini hanya disebut lagi dalam Kitab Yehezkiel (bukan Daniel dalam 1Taw. 3:1; Ezr. 8:2; Neh. 10:6). Komunitas Yahudi pasca-Pembuangan menganggap Daniel sebagai sosok orang benar (Yeh. 14:14, 20) dan orang bijak (Yeh. 28:3). ${ }^{19}$ Kalaupun Daniel dalam Kitab Yehezkiel dianggap sebagai sosok dari tradisi nonYahudi dan dikenal luas dalam tradisi Timur Tengah kuno, penulis Kitab Daniel tidak asing dengan sosok Daniel yang diasosiasikan dengan kitab itu, seperti halnya hukum Taurat diasosiasikan dengan Musa, mazmur dengan Daud, atau hikmat dengan Salomo. ${ }^{20}$

Bahasa Aram dalam Kitab Daniel tergolong bahasa Aram Kerajaan (bdk. 2Raj. 18:26), bahasa internasional di Timur Tengah selama abad ke6 SM hingga awal abad ke-2 SM. Bahasa Aram itu menyerap kosakata dari bahasa Akkadia dan Persia yang lebih tua. Juga ada tiga kata serapan

18 Gerhard von Rad, Old Testament Theology, pp. 306-308.

19 Daniel I. Block, The Book of Ezekiel: Chapters 1-24. The New International Commentary on the Old Testament (Grand Rapids: Eerdmans, 1997), pp. 447-449; John J. Collins, The Apocalyptic Imagination, p. 87.

20 Louis F. Hartman and Alexander A. Di Lella, The Book of Daniel, pp. 7-8. 
dari bahasa Yunani (kitharis, psalterion, symphonia) untuk beberapa alat musik (Dan. 3:5: "kecapi ... gambus, serdam"). ${ }^{21}$ Sintaksis bahasa Aram yang dipakai penulis Kitab Daniel mengindikasikan kitab itu berasal dari sebelah timur (bukan dari barat sebagai dokumen abad ke-2SM). ${ }^{22}$ Bentuk narasi bagian pertama juga cocok dengan latar cerita-cerita diaspora Yahudi di sebelah timur. ${ }^{23}$

Bagian berbahasa Aram Kitab Daniel (Dan. 2:4b-7:28) berciri sastra hikmat. Narasi-narasi dalam bagian pertama Kitab Daniel diperkirakan berasal dari abad ke-3 SM. ${ }^{24}$ Ada kesatuan tematis dengan struktur kiasmus. $^{25}$

Pasal 2 penglihatan tentang empat kerajaan

Pasal 3 selamat dari hukuman mati

Pasal 4 raja dikritik dan bertobat

Pasal 5 raja dikritik dan bertobat

Pasal 6 selamat dari hukuman mati

Pasal 7 penglihatan tentang empat kerajaan

Dalam peredaksian akhir, pasal terakhir bagian berbahasa Aram menjadi penyambung untuk bagian kedua dari kitab itu yang terkait penglihatan pada periode Makabe. Demikian kesatuan komposisi kitab itu. ${ }^{26}$ Perbedaan gaya bahasa dan kosakata bahasa Aram dalam Daniel 7 dibandingkan dengan pasal-pasal sebelumnya disebabkan oleh perbedaan pokok bahasan, bukan perbedaan karena perkembangan bahasa. ${ }^{27}$ Dengan

21 John J. Collins, Daniel, p. 184.

22 Jacques B. Doukhan, Daniel: The Vision of the End (Berrien Springs: Andrews University Press, 1987), pp. 118-119.

23 John E. Goldingay, Daniel: Word Biblical Commentary 30 (Dallas: Word Press, 1989), p. xxv.

24 Louis F. Hartman and Alexander A. Di Lella, The Book of Daniel, p. 13; Leo G. Perdue, The Sword and the Stylus: An Introduction to Wisdom in the Age of Empires (Grand Rapids: Eerdmans, 2008), p. 359.

25 S.M. Siahaan dan Robert M. Paterson, Kitab Daniel: Latar Belakang, Tafsiran dan Pesan (Jakarta: BPK Gunung Mulia, 1994), hlm. 28-30.

26 Louis F. Hartman and Alexander A. Di Lella, The Book of Daniel, p. 15; John J. Collins, Daniel: With an Introduction to Apocalyptic Literature (Grand Rapids: Eerdmans, 1984), p. 30.

27 John J. Collins, Daniel: Hermeneia (Minneapolis: Fortress Press, 1993), p. 17; bdk. W.S. LaSor, D.A. Hubbard, dan F.W. Bush, Pengantar Perjanjian Lama, p. 416. 
mengabaikan pergeseran lafal bahasa Aram sebagai sebuah bahasa hidup pada masa itu, bahasa Aram Kitab Daniel merujuk pada bahasa Aram yang lebih kemudian dari pada bahasa Aram dalam Papirus Elefantin (akhir abad ke-5 SM) namun berbeda dari bahasa Aram dalam Naskahnaskah Laut Mati (abad ke-3 sampai ke-2 SM). ${ }^{28}$ Itu berarti meliputi masa sesudah Aleksander Agung (356-323 SM), pada awal periode Helenistik namun lebih awal dari pada abad ke-2 SM.

Daniel menafsir mimpi dan mendapatkan penglihatan serta mendorong umat untuk hidup saleh sesuai dengan pernyataan yang diterimanya. Kaitan dengan kesalehan membuat hikmat dalam Kitab Daniel dapat dikatakan sebagai kelanjutan tradisi hikmat dalam Kitab Taurat. Umat yang melakukan perintah-perintah Allah dengan setia disebut "umat yang bijaksana" (Ul. 4:6). Hubungan hikmat dan tafsir mimpi juga sudah dikenal pada tradisi Ibrani awal dalam siklus Yusuf (Kej. 37: 39-50). ${ }^{29}$ Yusuf dijuluki kakak-kakaknya si tukang mimpi (Kej. 37:19), tetapi Firaun menyebut Yusuf yang mampu menafsir mimpi itu sebagai orang bijak (Kej. 41:39: "tidaklah ada orang yang demikian berakal budi dan bijaksana seperti engkau"). Ketika Yusuf menolak rayuan majikan perempuannya untuk berzinah, alasan yang dikemukakannya adalah "bagaimanakah mungkin aku melakukan kejahatan yang besar ini dan berbuat dosa terhadap Allah?" (Kej. 39:9). Sikap takut kepada Allah merupakan sebuah karakteristik tradisi hikmat (Ayb. 1:1; 28:28; Ams. 1:7;31:30; Pkh. 3:14; 12:13). ${ }^{30}$ Kemudian Yusuf difitnah majikannya dan dipenjarakan. Ciri ideal orang bijak adalah mengalami difitnah dan dipersulit, namun tetap hidup saleh dan kemudian dikaruniai tafsir mimpi tentang masa depan. ${ }^{31}$ Sosok Daniel berakar dalam tradisi orang bijak seperti itu.

28 John E. Goldingay, Daniel, p. xxv; John J. Collins, Daniel, p. 17.

29 John J. Collins, Daniel, pp. 39-40.

30 Bdk. Ayb. 1:1, 8f; 2:3; 28:28; Ams. 1:29; 2:5; 8:13; 9:10; 10:27; 14:2, 26f; 15:16, 33; 16:6; 19:23; 22:4; 28:14; 31:30; Pkh. 3:14; 7:18; 8:12f.

31 Gerhard von Rad, Old Testament Theology, p. 307; Leo G. Perdue, The Sword and the Stylus, p. 360. 
Kategori orang bijak dalam Kitab Daniel berbeda dari yang ada dalam Kitab Amsal. Dalam Kitab Amsal, orang bijak merupakan kontras orang bodoh, orang tidak berpengalaman, atau orang bebal (Ams. 1:7, 22). Dalam Kitab Daniel, orang bijak adalah kontras orang fasik (Dan. 12:10; berbeda juga dengan kontras antara orang benar dan fasik dalam Mzm. 1:1, 5f). Kendati sejalan dengan tradisi hikmat dalam Kitab Taurat, hikmat Daniel bukan hasil refleksi atas hukum Taurat (bdk. Mzm. 1:2), melainkan hikmat apokalips yang langsung diterima dari Allah melalui penglihatan dan mimpi (mantic wisdom). ${ }^{32}$ Meski belum ada konsensus tentang hikmat sebagai matriks apokaliptik Yahudi, ada kecenderungan untuk tidak membaca unsur hikmat apokalips sebagai hikmat tradisional yang berciri induktif.

Hikmat tradisional dalam Perjanjian Lama diperoleh melalui pemahaman rasional atas pepatah, teka-teki, pertanyaan, puisi, dan narasi pengajaran, sebagai hasil refleksi atas pengalaman empiris (Kitab Amsal) atau hasil refleksi rasional (Kitab Pengkhotbah dan Ayub). Objek observasi dalam hikmat tradisional adalah dunia alam dan manusia. Hikmat tradisional tidak terkait dengan sejarah Israel (ahistoris). Dalam literatur hikmat, terutama Yesus bin Sirakh, Allah digambarkan sebelumnya sudah mengetahui semua yang diciptakan-Nya dan juga masa-masa bagi segala sesuatu. Allah mengizinkan segala sesuatu terjadi sesuai dengan ketetapan-Nya. Bin Sirakh tergolong orang bijak meski bukan apokaliptis, tetapi apokaliptis pasti orang bijak. ${ }^{33}$

Dalam sastra apokalips, hikmat berfungsi untuk mengekspresikan pemahaman tentang penciptaan, eskatologi, dan pengetahuan, seperti halnya hikmat orang bijak dalam tradisi Yahudi pada abad ke-3 SM yang memanfaatkan unsur-unsur apokaliptik, terutama eskatologi. Kerangka hikmat apokalips adalah pengetahuan esoteris, bukan pengetahuan universal. Objek observasinya adalah dunia supernatural (surga) dan masa depan. Meski

32 John J. Collins, Jewish Wisdom in the Hellenistic Age (Louisville: Westminster John Knox Press, 1997), pp. 227-229; John E. Goldingay, Daniel, p. 324; Leo G. Perdue, The Sword and the Stylus, pp. 359-361.

33 Gerhard von Rad, Wisdom in Israel, translated by J.D. Martin (London: SCM Press, 1972), pp. 263-283. 
mimpi Nebukadnezar tentang patung raksasa (Dan. 2:31-45) dan penglihatan Daniel tentang empat binatang besar (Dan. 7:2-27) tidak menyinggung sejarah Israel, kerajaan-kerajaan dunia digambarkan bergerak ke tujuan di luar sejarah ini, suatu tujuan yang diarahkan oleh Sang Penguasa sejarah. Allah berurusan dengan kerajaan-kerajaan dunia dan sosok eskatologis datang "dari langit seorang seperti anak manusia" (Dan. 7:13 bar 'enaš), tidak berasal dari dunia ini. ${ }^{34}$ Sosok seperti anak manusia itu lebih dekat dengan gambaran makhluk dalam Apokalips Hewan (1Hen. 87:2), bukan dengan "anak manusia" (Dan. 8:17 ben-'adam), sapaan malaikat untuk Daniel (Yehezkiel juga berulang kali disapa Allah demikian). Israel akan mengalami kesukaran besar namun akan diselamatkan pada masa eskatologis. Karena Allah adalah Sang Pencipta sekaligus Sang Penguasa dunia, wajarlah akhir dunia menjadi objek refleksi dalam hikmat apokalips.

Nubuat dan hikmat di Israel setidak-tidaknya menjadi sumber apokaliptik Yahudi. ${ }^{35}$ Masuknya matriks hikmat dalam studi tentang apokalips ini merevisi pemahaman sebelumnya yang mengaitkan apokalips dengan ideologi sosio-religius. Memang apokalips pertama kali jelas pada periode Helenistik dan berpengaruh sampai periode Imperium Romawi (70 M), namun unsur-unsurnya jauh sedini periode Imperium Persia. ${ }^{36}$ Ada perkembangan gagasan tentang apokalips dalam Perjanjian Lama. Awalnya, gagasan tentang apokalips tersebar dalam kitab nabi-nabi sebagai hasil peredaksian di kemudian hari, seperti gambaran perang dalam Kitab Mikha (Mi. 4:11-13), nubuat tentang Gog dan Magog dalam Kitab Yehezkiel (Yeh. 38-39), tambahan dalam Yesaya Ketiga (Yes. 65:17-25; 66:20,2224), tambahan dalam beberapa mazmur (Mzm. 22:28-32; 69:31-37). ${ }^{37}$ Selanjutnya, apokalips dalam bentuk unit-unit teks yang kecil (Yes. 24-27; Y1. 2:28-3:1/3:1-4:1; Za. 9-14). Akhirnya, apokalips ditemukan dalam bentuk sebuah tulisan utuh (Kitab Daniel).

34 John J. Collins, Daniel, pp. 305-306.

35 Leo G. Perdue, The Sword and the Stylus, pp. 356, 360, 365-366.

36 Leo G. Perdue, The Sword and the Stylus, pp. 364-365.

37 Horst D. Preuss, Old Testament Theology, Vol. 2, translated by Leo G. Perdue (Louisville: Westminster John Knox Press, 1996), pp. 277-283. 
Teks-teks proto-apokaliptik dalam kitab nabi-nabi mungkin merupakan produk kelompok marjinal yang tersingkir karena kalah bertarung secara politik dalam masyarakat Yahudi yang baru terbentuk sekembalinya mereka dari Pembuangan. ${ }^{38}$ Redaktor beberapa kitab nabi semasa akhir pemerintahan dinasti Akhaemenid (abad ke-5 dan awal abad ke-4 SM) tampaknya merupakan bagian dari sebuah kelompok juru tulis di lingkungan Bait Suci. Para juru tulis itu bertanggungjawab atas unsur apokaliptik untuk kitab nabi-nabi. Ideologi mereka moderat dan ideal pahlawan mereka adalah visionaris seperti Henokh dan Daniel. Sebagai kelompok marjinal yang mengharapkan kejatuhan penguasa kafir, pada suatu waktu pada periode awal Helenistik, mungkin mereka tidak disukai lagi oleh kaum Zadok yang pada waktu itu berkuasa atas Bait Suci. Mereka adalah imamimam Yerusalem yang mengakomodasi kepentingan penguasa. Selama Yudea di bawah kekuasaan pemerintah Helenistik, kelompok-kelompok marjinal di lingkungan Bait Suci tetap ada, dan partisipasi mereka dibatasi kaum imam yang pro-penguasa kolonial (Yunani, kemudian Romawi). Ada di antara kelompok marjinal itu yang menganut pandangan (hikmat) apokaliptik dan warisan mereka adalah literatur apokaliptik yang merespons krisis sosial sebagai akibat tekanan dari penguasa dan kaum konservatif agama yang pro-status quo (kaum Zadok dan pendukung hikmat tradisional). Dinamika dari hikmat apokaliptik masih terasa dalam agama Yahudi sampai setelah pemberontakan Bar Kokhba yang gagal (132-135 M). Sejak itu, secara definitif orang Yahudi mengadopsi kepemimpinan rabi dan apokaliptik tidak punya pengaruh lagi.

Memang banyak tulisan apokaliptik dilatarbelakangi oleh krisis sosial atau krisis iman, namun itu tidak berarti apokaliptik selalu produk gerakan sosial kaum marjinal (gerakan apokaliptik). Apokaliptik bertumbuh kembang dalam lebih dari satu latar tradisi sosial. ${ }^{39}$ Kalau apokaliptik Yahudi berasal dari lingkungan orang bijak (kaum terdidik), mereka tentu bukan kelompok marjinal. Kitab Daniel tidak dapat sepenuhnya dikaitkan

38 Paul D. Hanson, The Dawn of Apocalyptic: The Historical and Sociological Roots of Jewish Apocalyptic Eschatology (Philadelphia: Fortress Press, 1979), pp. 27-29.

39 John J. Collins, The Apocalyptic Imagination, pp. 37-41. 
dengan Revolusi Makabe. Ada perbedaan ideologi antara Kitab 1Makabe dan Daniel 7-12 (secara ideologis lebih dekat dengan Kitab 2Makabe). ${ }^{40}$ Kitab 1Makabe menegaskan tindakan radikal keluarga Makabe dan tidak menyinggung kebangkitan orang mati. Dalam sejarah Yahudi kemudian, orang bijak diidentifikasi sebagai Hasidim yang melawan penguasa yang menghina agama mereka (bdk. 1Mak. 2:42; 7:12f; 2Mak. 14:6). Namun, identifikasi orang bijak menurut Kitab Daniel bersifat terbuka, tidak eksklusif untuk kaum yang mati syahid, melainkan untuk siapa saja yang setia beriman, yang berharap kepada Allah kendati nyawa mereka terancam, yang menuntun orang di jalan yang benar, dan yang mengkritik arogansi kekuasaan. Keselamatan yang dibayangkan komunitas apokaliptik adalah kerajaan yang melampaui kerajaan fisik (bdk. Mat. 6:10: “datanglah kerajaan-Mu, jadilah kehendak-Mu di bumi seperti di surga"), keselamatan bukan oleh kekuatan militer atau kekuasaan duniawi, tetapi oleh Allah yang bertindak dalam sejarah. Demikian penguasa lalim mendapat tandingan dari orang bijak. Namun, kerangka konseptual sastra apokaliptik ternyata juga berciri eskatologis.

\section{ESKATOLOGI}

Awalnya, para ahli tidak mengaitkan apokaliptik dengan eskatologi yang merupakan pendatang belakangan dalam teologi Kristen. Apalagi, pamor eskatologi kalah dibandingkan dengan kristologi (doktrin tentang person Kristus), soteriologi (doktrin tentang karya penebusan Kristus), atau eklesiologi (tentang Gereja) ${ }^{41}$ Dalam dogmatika, eskatologi selalu menempati bab terakhir, seolah-olah sebagai apendiks. Demikianlah eskatologi, terutama apokalips, kurang diperhitungkan dalam berteologi sampai teolog seperti Pannenberg dan Käsemann menyadarkan signifikansinya bagi teologi. Meski sangat jarang dalam hikmat tradisional, unsur eskatologis berperan penting dalam banyak tulisan apokaliptik.

40 John E. Goldingay, Daniel, p. xxvi.

41 Klaus Koch, The Rediscovery of Apocalyptic, translated by M. Kohl (London: SCM Press, 1972), pp. 98-101. 
Tradisi membaca Kitab Daniel dalam konteks akhir zaman dapat ditelusuri dari satu-satunya penyebutan tokoh kitab itu dalam Perjanjian Baru (Mat. 24:15: "Nabi Daniel"), dalam konteks wejangan Yesus tentang akhir zaman. Kitab itu secara mencolok memang memakai kosa kata Ibrani dan Aram yang berarti "akhir." Dari total 67 kali kata Ibrani qeș (dengan variannya qeșe, qaṣe, qaṣa), terbanyak (15 kali) dalam kitab itu (Dan. 8:17, 19; *9:26, 26; 11:6, 13: "kemudian"; 11:27, 35, 40; 11:45: "ajal"; 12:4, 6, 9; *12:13, bis). Kata qeș bisa dipakai dalam arti abstrak (Pkh. 12:12: "akhirnya"), spasial (Kej 47:21: “ujung") dan temporal (Hab. 2:3: "kesudahannya"). Namun, makna temporal qeṣ justru paling sering dipakai. ${ }^{42}$ Dalam Kitab Daniel, qeṣ lebih sering berarti akhir suatu masa (Dan. 8:17, 19; 11:27,35,40; 12:4,6f,9 namun diterjemahkan "akhir zaman") dan hanya dua kali yang benar-benar berarti akhir zaman (Dan. 12:13). ${ }^{43}$ Dari total 8 kali kata Aram sop, terbanyak (5 kali) juga dalam kitab itu (Dan. 4:11/8, 22/ 19: "ujung"; 6:27: “berakhir"; 7:26: “lenyap"; 7:28: “sekianlah"). Dari situ, dapat dikatakan Kitab Daniel adalah kitab tentang akhir (yang menentukan). ${ }^{44}$ Kitab itu dibuka dengan gambaran Yoyakim raja Yehuda dihukum sekaligus riwayat kerajaan itu menemui akhirnya (Dan. 1:1f). Kitab itu ditutup dengan Daniel yang memiliki kesadaran mendalam tentang akhir hidupnya sendiri (Dan. 12:2,13).

Kata Ibrani lain untuk "akhir" adalah 'aharit(seakar dengan kata Indonesia "akhir" dan "akhirat" yang diserap dari bahasa Arab). Itulah padanan untuk kata Yunani eschatos. Kata 'aharit dapat berarti akhir secara kronologis atau akhir sesuatu. ${ }^{45}$ Secara kronologis, 'aharit berarti "masa depan" (Ams. 23:18; 24:14), "hari depan” (Yer. 29:11), atau "hal yang kemudian" (Yes. 46:10). Dalam arti itu, bĕ'aharit hayyamim ("di kemudian hari") merujuk suatu waktu terbatas di masa depan, bukan dalam arti

42 S. Talmon, "qes," in Theological Dictionary of the Old Testament, Vol. 13, edited by G. Johannes Botterweck, H. Ringgren, and H.-J. Fabry, translated by David E. Green (Grand Rapids: Eerdmans, 2004), pp, 79-82.

43 S. Talmon, "qeș," p. 83.

44 Jacques B. Doukhan, Daniel, pp. vii-viii.

45 Horst Seebass, "'acharit," in Theological Dictionary of the Old Testament, Vol. 1, edited by G. Johannes Botterweck and H. Ringgren (Grand Rapids: Eerdmans, 1977), pp. 207-212. 
eskatologis "pada hari-hari yang terakhir" (Kej. 49:1; Bil. 24:14; Ul. 4:30; 31:29; *Yer. 23:20/ /30:24; 48:47, tidak ada dalam LXX; 49:39). Namun, juga 'aharit dapat dimaknai sebagai akhir dari sesuatu (Ul. 8:16; Ams. 25:8; Dan. 8:23; 12:8; Am. 8:10: "akhir"; Bil. 23:10: "ajal"; *Yer. 17:11: "akhir hidup"; Ul. 32:20: “kesudahan”; Mzm. 139:9: “ujung”). Hanya enam kali ungkapan bӗ'aharithayyamim dimengerti sebagai masa depan eskatologis (Yes. 2:2//Mi. 4:1; Yeh. 38:16; Dan. 10:14: "pada hari-hari yang terakhir"; Hos. 3:5: "in the last days," NIV, NAB; NJB: "in the final days"; Dan. 2:28: "in the final days," NJB; TNK: "at the end of days"). Akhir dalam perspektif Perjanjian Lama sebenarnya bukan akhir dunia atau sejarah begitu saja, melainkan akhir dari keburukan yang dapat diakhiri sepenuhnya hanya oleh Allah (Mi. 4:3/ /Yes. 2:4: perang; Yeh. 36:30: kelaparan; Yes. 35:5f: penyakit dan cacat fisik; Yes. 65:25: perbuatan jahat; Yer. 33:8: dosa). ${ }^{46}$

Unsur-unsur mitologis hadir secara sporadis dalam teks-teks nubuat eskatologis, dan para nabi (Amos sampai Yesaya Ketiga) mendapat penglihatan tentang peristiwa-peristiwa yang menentukan akhir zaman. Hari TUHAN (yom yhwh) dipahami sebagai bagian dari pengalaman historis zaman ini (eskatologi realistik). Teks Yesaya 65:17-25, misalnya, mulai dengan penglihatan yang berpengaruh yang awalnya mengatasi dunia ini seluruhnya, "Aku menciptakan langit yang baru dan bumi yang baru; halhal yang dahulu tidak akan diingat lagi dan tidak akan timbul lagi dalam hati" (ay. 17). Setelah membicarakan dunia yang betul-betul baru, Yesaya langsung kembali ke hal-hal di dunia ini:

Mereka akan mendirikan rumah-rumah dan mendiaminya juga; mereka akan menanami kebun-kebun anggur dan memakan buahnya juga. Mereka tidak akan mendirikan sesuatu, supaya orang lain mendiaminya, dan mereka tidak akan menanam sesuatu, supaya orang lain memakan buahnya; sebab umur umat-Ku akan sepanjang umur pohon, dan orangorang pilihan-Ku akan menikmati pekerjaan tangan mereka (ay. 21f).

Kitab Yeremia juga menyebut sebuah masa ketika umat akan hidup dalam persekutuan dengan Allah tanpa hambatan apa pun; sebuah situasi 
kehidupan yang tidak terjadi di dunia ini. Dalam kitab itu dituliskan: “Beginilah perjanjian yang Kuadakan dengan kaum Israel sesudah waktu itu, demikianlah firman TUHAN: Aku akan menaruh Taurat-Ku dalam batin mereka dan menuliskannya dalam hati mereka; maka Aku akan menjadi Allah mereka dan mereka akan menjadi umat-Ku" (Yer. 31:33). Rekonsiliasi seperti itu tidak pernah terjadi sebelumnya, bahkan tidak akan terjadi sebuah dunia terbaik dari semua kemungkinan dunia yang dapat dipikirkan (the best of all possible world). Kendati demikian, yang dibicarakan tetap dunia ini, tentang TUHAN memilih Israel dan tentang perjanjian yang ditulis dalam hati mereka. Nubuat eskatologis merujuk kepada suatu zaman baru yang akan datang. Itu sebuah perspektif tentang masa depan Israel dan dunia sebagaimana dalam rencana Allah yang dinyatakan kepada nabi dan kemudian disampaikan kepada raja dan rakyat, dengan memperlihatkan penggenapan rencana ilahi itu dalam peristiwa-peristiwa sejarah dan politik yang melibatkan manusia dalam penggenapannya. Apokalips mesti bersifat eskatologis, namun eskatologi tidak mesti apokaliptik.

Meski sarat dengan unsur-unsur mitologis, eskatologi apokaliptik mengajak orang untuk menjadikan akhir sebagai objek refleksi, bukan untuk menjadi pesimistis, melainkan untuk lebih arif menjalani hidup, untuk tidak menjadi pelaku kejahatan dan keburukan, sebagai syarat menjadi penghuni langit dan bumi baru. Cara apokaliptik memandang realitas radikal, melawan status quo, melibatkan transformasi pengetahuan, perspektif, dan komitmen. ${ }^{47}$ Sistem yang sekarang berlaku tidak dapat diharapkan sebagai solusi krisis masa depan. Pihak yang diuntungkan oleh sistem cenderung menutup mata terhadap akar masalah ketidakadilan, menganggap segala sesuatu sudah berjalan sebagaimana mestinya. Agama institusional dipakai untuk melegitimasi ketidakadilan dan penindasan. Di situlah perspektif apokaliptik menukik ke akar penyebab ketidakadilan dan penindasan. Kejahatan akan mencapai puncaknya namun untuk disingkirkan selamalamanya. Tatanan hidup akan ditata ulang secara radikal dan langsung oleh Allah.

47 Paul D. Hanson, Old Testament Apocalyptic: Interpreting Biblical Texts (Nashville: Abingdon Press, 1987), pp. 15-24. 
Dalam matriks hikmat, masa akhir sebagai objek apokaliptik justru mencakup masa kini. Menurut kesimpulan Qohelet, "akhir ('aharit) suatu hal lebih baik dari pada awalnya" (Pkh. 7:8). Akhir dalam konteks ini adalah kematian. Pergi ke rumah duka lebih baik dari pada pergi ke rumah pesta karena di rumah dukalah kesudahan setiap manusia. Hari kematian lebih baik dari pada hari kelahiran, bukan dalam arti lebih baik mati dari pada hidup (Pkh. 7:16f), melainkan kesadaran akan kefanaan hidup dan kemati-an akan datang kapan saja, memotivasi orang untuk meninggalkan perilaku bodoh dan hidup lebih arif (Pkh. 7:1b-4). Berdasarkan fakta bahwa masa hidup manusia sekitar 70 tahun atau, kalau kuat, 80 tahun, pemazmur berdoa: "Ajarlah kami menghitung hari-hari kami sedemikian, hingga kami beroleh hati yang bijaksana" (Mzm. 90:12).

\section{ASPEK NONSEKTARIAN APOKALIPTIK}

Aspek nubuat dan eskatologis apokalips Kitab Daniel membuat pembaca berjarak dengan dunia, namun aspek hikmat membuat pembaca terlibat dan serius dengan dunia. Hikmat apokaliptik menekankan hidup berhikmat dan sebagai demikian merupakan sebuah produk Yudaisme arus utama. Hal itu menjadi salah satu faktor penerimaan Kitab Daniel dalam kanon Yahudi sebagaimana ditegaskan dalam teks-teks berikut.

Horizon kitab itu adalah seluruh bangsa Yahudi dengan hukum Taurat sebagai standar moral dan wejangan para pemimpin bangsa Israel. Petaka bangsa Yahudi hingga mereka ditawan ke Pembuangan sudah sesuai "seperti yang tertulis dalam kitab Taurat Musa" (Dan. 9:13). Ungkapan "kami" dalam doa pengakuan dosa merujuk kepada "bangsa" Yahudi yang dibuang ke Babel (Dan. 9:20; bdk. 9:6: “segenap rakyat negeri"; 9:7,11: "segenap orang Israel"). Demikian hukum Taurat tetap menjadi standar moral umat di Pembuangan (Dan. 9:6, 8, 10f; bdk. Ezr. 9:6-15; Neh. 9:6-37). Ada juga praktik rukun agama yang tidak tercantum dalam hukum Taurat, namun menjadi bagian dari kesalehan umat, seperti doa harian pada waktu-waktu tertentu dengan berkiblat ke Yerusalem (Dan. 6:11,14; bdk. 1Raj. 8:44, 48). 
Pendahuluan kitab itu (Dan. 1) mengisahkan ujian umat untuk memelihara kemandirian batin mereka di Pembuangan. Jati diri keumatan mereka dikikis secara sistematis mulai dari mereka diprogram (babilonisasi) untuk menguasai ilmu orang Kasdim dan nama Yahudi mereka diganti dengan nama Babel. Untuk makanan sehari-hari pun Daniel dan ketiga sahabatnya mendapat jatah dari santapan raja. Namun, Daniel menolak kebergantungan pada makanan dari meja raja dengan alasan keagamaan (ay. 8: "tidak menajiskan dirinya"). Sebenarnya teks tidak menyebut apakah makanan itu sebelumnya sudah dipersembahkan kepada dewa Babel, mengandung darah, atau mengandung daging haram menurut hukum Yahudi. Apakah itu hanya sekadar alasan, yang jelas Daniel ingin mempertahankan sebuah ruang kemandirian dalam kehidupan pribadi-nya terkait dengan makanan. Meski sebagai tawanan tidak ada pilihan lain selain mengabdi kepada Babel, Daniel ingin memberikan ruang kepada pemeliharaan Tuhan dan cukup menerima makanan biasa. Ihwal menolak makanan enak dari penguasa juga terdapat dalam Kitab Yudit yang merefleksikan masa Makabe (Ydt. 12:2-4). Ketika diberi makan dari menu Holofernes, Yudit menolak dan memilih makan dari yang dibawanya sendiri, dengan alasan agar tidak menjadi batu sandungan. Ketika Holofernes khawatir makanan yang dibawa itu tidak cukup, wanita itu dengan yakin berkata bahwa sebelum makanannya habis, Tuhan akan melakukan apa yang direncanakan-Nya melalui dirinya. Ia pun kemudian menjadi pahlawan bagi umat Allah karena membebaskan mereka dari tangan Holofernes.

Menjadi saleh tidak berarti menjauh dari dunia politik. Babilonisasi Daniel dan ketiga sahabatnya berakhir dengan promosi mereka dari status tawanan ke status elite istana. Daniel digambarkan bekerja sejak masa Nebukadnezar raja Babel hingga Koresh raja Persia, pada 538 SM (Dan. 1:21), sempat menjadi pejabat tertinggi ketiga semasa Belsyazar (Dan. 5:16, 29). Karier Daniel berlanjut sampai ketika Persia menggantikan kedigdayaan Babel pada 536 SM (Dan. 10:1). Daniel tetap dipakai dalam Imperium Persia dengan total karier sebagai pejabat tinggi lebih dari enam dekade (598-536 SM). Ia bekerja sebagai profesional, “Pernahkah engkau melihat orang yang cakap dalam pekerjaannya? Di hadapan raja-raja ia akan ber- 
diri, bukan di hadapan orang-orang yang hina" (Ams. 22:29). Kehidupan Daniel sesuai dengan wejangan Nabi Yeremia agar umat di Pembuangan mengupayakan kesejahteraan negeri ke mana mereka dibuang dan dengan begitu hidup mereka pun akan terjamin (Yer. 29:7). Dalam pengabdiannya kepada penguasa asing, Daniel tetap memelihara imannya tanpa kompromi.

Loyalitas tunggal kepada Allah yang diperlihatkan Daniel menegaskan universalitas pemerintahan Allah yang menghukum dan memberkati umat, yang menentang arogansi kekuasaan. ${ }^{48}$ Saat Nebukadnezar berjalanjalan di bagian atas istananya, ia merasa kebesaran Babel karena kekuatannya dan untuk kemuliaannya (Dan. 4:29f/26f). Padahal, di mata Sang Raja segala raja, Nebukadnezar akan seperti pohon yang ditebang, dahandahannya dipotong, daun-daunnya berguguran, buah-buahnya berhamburan, sehingga binatang-binatang yang tadinya bernaung dan bertengger pada pohon itu akan lari (Dan. 4:14/11). Allah "berkuasa atas kerajaan manusia dan memberikannya kepada siapa yang dikehendaki-Nya" (Dan. 4:17/14; bdk. 2:21: "Dia memecat raja dan mengangkat raja"). Sebelum selesai sikap jumawanya itu, terdengar suara dari langit bahwa kerajaan Nebukadnezar sudah beralih dari dirinya. Ia akan dihalau dari antara manusia, tinggal di antara binatang-binatang di padang, makan rumput seperti lembu, demikian keadaan dirinya sampai ia mengakui bahwa Allah berkuasa atas kerajaan manusia dan memberikan kuasa memerintah kepada siapa yang dikehendaki-Nya (Dan. 4:31f/28f).

Saat Belsyazar mabuk dan memuji-muji dewa-dewa Babel yang terbuat dari emas, perak, tembaga, kayu dan batu, raja itu meninggikan diri terhadap Allah yang menggenggam napas hidupnya dan menentukan jalan hidupnya (Dan. 5:23). Muncul tulisan mene, mene, tekel ufarsin secara gaib pada dinding istana: mene berarti masa pemerintahan raja telah dihitung Allah dan diakhiri, tekel berarti raja ditimbang dengan neraca dan ternyata terlalu ringan, peres berarti kerajaan itu pecah dan diberikan kepada Kerajaan Media dan Persia (Dan. 5:25-28).

48 John Barton, Understanding Old Testament Ethics: Approaches and Explorations (Louisville: Westminster John Knox Press, 2003), pp. 154-161. 
Raja Darius juga terjebak dalam arogansi kekuasaan dan meninggikan diri terhadap Allah dengan mengundang-undangkan peraturan bahwa selama 30 hari ke depan dilarang menyampaikan permohonan apa pun kepada manusia, bahkan kepada yang ilahi, kecuali kepada raja. Pelanggarnya akan dilempar ke dalam gua singa. Tetapi Daniel tetap melakukan kebiasaannya berdoa tiga kali sehari pada waktu-waktu tertentu di kamarnya dengan jendela kamar terbuka dan sikap doa berkiblat ke Yerusalem (Dan. 6:11,14). Hukum pun menjeratnya. Namun secara ajaib ia ditolong Allah dan luput dari kebuasan singa-singa. Darius pun mengakui kekuasaan Allah dan memberi titah untuk seluruh kerajaannya: "Orang harus takut dan gentar kepada Allahnya Daniel, sebab Dialah Allah yang hidup, yang kekal untuk selama-lamanya; pemerintahan-Nya tidak akan binasa dan kekuasaan-Nya tidak akan berakhir" (Dan. 6:27).

Dari bagian pertama Kitab Daniel muncul gagasan bahwa betapapun terancamnya nyawa orang saleh, mereka akhirnya selamat (Dan. 3, 6). Kesetiaan tanpa pamrih dan hukuman oleh penguasa merupakan ciri kesalehan agama Yahudi periode kedua dari Bait Suci (Tob. 1:18). Betapapun arogannya penguasa non-Yahudi, akhirnya mereka bertobat, bukan untuk memeluk agama Yahudi, tetapi dari arogansi kekuasaan, untuk mengakui bahwa kekuasaan politik pada akhirnya juga harus dipertanggungjawabkan kepada Allah (Dan. 4:25/22: “Yang Mahatinggi berkuasa atas kerajaan manusia dan memberikannya kepada siapa yang dikehendaki-Nya"). Para penguasa dunia itu menyebut Allah Israel bukan dengan sebutan eksklusif Yahwe, melainkan dengan sebutan yang menegaskan kemahakuasaan (Dan. 2:47: "Allah yang mengatasi segala ilah dan Yang berkuasa atas segala raja"; 4:2/3:32: "Allah yang mahatinggi"; 4:34/31: "Yang Mahatinggi"; 4:37/34: "Raja Surga"; 6:21,27: "Allah yang hidup"). ${ }^{49}$

49 Saat berbicara kepada penguasa non-Yahudi, Daniel tidak menyebut nama Yahwe (Dan. 2:37, 44: "Allah semesta langit"; 2:45: "Allah yang mahabesar"; 4:26/23: "Surga"), tetapi nama Allah Israel itu muncul dalam doa pribadinya (Dan. 9:2, 4, 8, $10,13 f, 20)$. 


\section{PENUTUP}

Penulis Kitab Daniel mungkin hidup semasa Makabe, namun sifat apokaliptik kitab itu bukan produk masa Makabe, melainkan dari tradisi pra-Makabe yang berakar pada tradisi nubuat, hikmat, dan eskatologi. Apokaliptik Daniel adalah jalan untuk memahami akhir zaman, bukan untuk menjauh dari dunia, melainkan untuk hidup berhikmat di dunia.

Kitab Daniel memperlihatkan segelintir orang saleh yang menjadi bagian dari lingkaran kekuasaan, sebagai bagian dari minoritas berkualitas, sebagai suara yang harus didengar penguasa. Pesan utama kitab itu adalah bahwa rencana Tuhan untuk menyelamatkan dunia tidak akan gagal..$^{50}$ Beriman kepada Tuhan langit dan bumi baru berarti bila orang berpartisipasi di dunia sebagai pelaku sejarah, menulis sejarah-sejarah kecil, di bawah bimbingan Sang Penguasa sejarah. Sejarah pada dasarnya adalah sejarah manusia bersama Allah, sejarah Allah bersama manusia. Dari pada apatis, kaum saleh yang menderita tetap berkarya, bersama siapa saja yang berkehendak baik, demi kebaikan dan keselamatan bersama, demi masa depan bersama, yang kesempurnaannya dikerjakan oleh Allah Yang Mahakuasa. Penentu masa depan bukan penindasan, melainkan kebenaran, kebaikan, dan kesetiaan umat. Semua yang beriman dan setia pada akhirnya menjadi bagian dari barisan pemenang.

\section{DAFTAR RUJUKAN}

Albertz, Rainer. A History of Israelite Religion in the Old Testament Period. Vol. 2. Translated by J. Bowden. Louisville: Westminster John Knox Press, 1994.

Barton, John. Understanding Old Testament Ethics: Approaches and Explorations. Louisville: Westminster John Knox Press, 2003.

Beckwith, Roger. The Old Testament Canon of the New Testament Church. Grand Rapids: Eerdmans, 1985.

Block, Daniel I. The Book of Ezekiel: Chapters 1-24. The New International Commentary on the Old Testament. Grand Rapids: Eerdmans, 1997.

50 W. Sibley Towner, Daniel: Interpretation, a Bible Commentary for Teaching and Preaching (Atlanta: John Knox Press, 1984), pp. 2-4. 
Blommendaal, J. Pengantar kepada Perjanjian Lama. Jakarta: BPK Gunung Mulia, 1979.

Collins, John J. The Apocalyptic Imagination: An Introduction to Jewish Apocalyptic Literature. Ed. 2. The Biblical Resource Series. Grand Rapids: Eerdmans, 1998.

. Daniel: Hermeneia. Minneapolis: Fortress Press, 1993.

. Daniel: With an Introduction to Apocalyptic Literature. Grand Rapids: Eerdmans, 1984.

. Jewish Wisdom in the Hellenistic Age. Louisville: Westminster John Knox Press, 1997.

Doukhan, Jacques B. Daniel: The Vision of the End. Berrien Springs: Andrews Uiversity Press, 1987.

Goldingay, John E. Daniel. Dallas: Word Press, 1989.

Gowan, Donald E. Eschatology in the Old Testament. Philadelphia: Fortress Press, 1986.

Hanson, Paul D. The Dawn of Apocalyptic: The Historical and Sociological Roots of Jewish Apocalyptic Eschatology. Philadelphia: Fortress Press, 1979.

. Old Testament Apocalyptic: Interpreting Biblical Texts. Nashville: Abingdon Press, 1987.

Hartman, Louis F. and Alexander A. Di Lella. The Book of Daniel. The Anchor Bible 23. New York: Doubleday, 1978.

Koch, Klaus. The Rediscovery of Apocalyptic. Translated by M. Kohl. London: SCM Press, 1972.

LaSor, W.S., D.A. Hubbard, dan F.W. Bush. Pengantar Perjanjian Lama: Sastra dan Nubuat. Jilid 2. Terjemahan: L.W. Tjiputra. Jakarta: BPK Gunung Mulia, 1994.

ten Napel, Henk. Kamus Teologi Inggris-Indonesia. Jakarta: BPK Gunung Mulia, 1994.

O'Collins, Gerald dan Edward G. Farrugia. Kamus Teologi. Terjemahan: I. Suharyo. Yogyakarta: Kanisius, 1996.

Perdue, Leo G. The Sword and the Stylus: An Introduction to Wisdom in the Age of Empires. Grand Rapids: Eerdmans, 2008.

Preuss, Horst D. Old Testament Theology. Vol. 2. Translated by Leo G. Perdue. Louisville: Westminster John Knox Press, 1996.

von Rad, Gerhard. Old Testament Theology. Vol. 2. Translated by W.G. Stalker. New York: Harper \& Row, 1965. 
.Wisdom in Israel. Translated by J.D. Martin. London: SCM Press, 1972.

Reddish, Mitchell G., ed. Apocalyptic Literature: A Reader. Nahville: Abingdon Press, 1990.

Rendtoff, Rolf. The Canonical Hebrew Bible: A Theology of the Old Testament. Translated by David E. Orton. Leiden: Deo, 2005.

Russell, D.S. The Method and Message of Jewish Apocalyptic: 200 BC - AD 100. Philadelphia: Westminster Press, 1964.

Seebass, Horst. "'acharit." In Theological Dictionary of the Old Testament, eds. G. Johannes Botterweck and H. Ringgren, Vol. 1. Translated by John T. Willis. Grand Rapids: Eerdmans, 1977, pp. 207-212.

Siahaan, S.M. dan Robert M. Paterson. Kitab Daniel: Latar Belakang, Tafsiran dan Pesan. Jakarta: BPK Gunung Mulia, 1994.

Skober, Tandi. “Apokaliptisisme Densus 88." Media Indonesia, 8 September 2012, Opini: 25.

Talmon, S. "qeș." In Theological Dictionary of the Old Testament, eds. G. Johannes Botterweck, H. Ringgren, and H. J. Fabry, Vol. 13. Translated by David E. Green. Grand Rapids: Eerdmans, 2004, 78-86.

Towner, W. Sibley. Daniel: Interpretation, a Bible Commentary for Teaching and Preaching. Atlanta: John Knox Press, 1984.

Weber, Max. Ancient Judaism. Translated by H.H. Gerth and D. Martindale. New York: Free Press, 1952. 